\title{
INSURANCE AGAINST TEMPORARY DISABILITY: A BLUEPRINT FOR STATE ACTION
}

Loss of wages is the major risk to workers in modern industrial society. When wages are interrupted, laborers who have little savings and no other source of income face severe economic privation. ${ }^{1}$ And when a worker is the sole breadwinner of a family, his wage loss is likely to bring poverty and ill-health upon the entire household. ${ }^{2}$

To protect workers and their families from some of the economic consequences of income loss, a network of social security laws has been developed. Old age and survivor's insurance (OASI) offers limited compensation for unemployment resulting from superannuation and premature death. ${ }^{3}$ Unemployment insurance ${ }^{4}$ partially indemnifies able-bodied workers ${ }^{5}$ for income

1. "The vast majority of wage earners are dependent for their livelihood solely or mainly on the regular exercise of some trade. When this activity stops temporarily or permanently, owing to an industrial accident, sickness, invalidity, old age, premature death or involuntary unemployment, the income of the worker's family is seriously affected or completely disappears." InTERnatronal Labour OfFice, Soctar Insurance 1 (Studies and Reports, Series M, No. 12, 1936). The economic consequences are of greater severity in the worker's case, "than in the middle classes deriving their income from property, business, or profession, where the continuity of income is not so closely dependent upon continuity of effort." Rubinow, Social Insurance 8 (1916). Further on this theme are Pink, Freedom From Fear (1944); Millis \& Montgomery, Labor's Risks and Social. INSURANCE (1938).

2. In an agricultural society almost every member of a household unit contributes to the sustenance of the family. But although today the family remains the basic economic unit, industrialization has made the economic security of nine out of every ten American families hinge upon the labor of one individual. When his labor is terminated, his entire ménage suffers from his wage loss. Falk, Read \& Sanders, Some Problems in the Formullation of a Disability Insurance Program, 6 LAw \& Contens. Pror. 645 (1939).

3. On the problem of the industrially old worker, see Millis \& MonTGOMERY, LaBor's Risks and Social Insurance 353-408 (1938); Muntz, Growth and Trends in Social Security, National Industrial Conference Board, Studies in Industrial and Collective Security No. 6, 125-160 (1949) (Hereinafter cited as NICB, Studies No.) (Hereinafter, Old Age and Survivor's Insurance will be cited as OASI).

4. For a comprehensive analysis of unemployment insurance in the United States, see Burns, Unemployment Compensation and Socio-Economic Objectives, 55 Y ALE L. J. 1 (1945); Witte, Development of Unemployment Compensation, id. at 21.

5. Thirty-four state laws require that the claimant, to be eligible for unemployment benefits, be "able to work and available for work." Freeman, Able to Work and Available For Work, 55 YALE L. J. 123, 124 n. 8 (1945). Most of the others have similar provisions. Ibid.

Five states have amended this requirement in an attempt to plug the gap in social insurance protection afforded their workers. These states provide that a worker is not ineligible for unemployment benefits if disability occurs after he registers for work or files a claim for benefits and no suitable work can be found after his illness began. Md. Laws c. 270, \$4(c) (1945) ; Mont. Laws c. 19, \$4 (c) (1945) ; Nev. Stats. c. 187, § 4(c) (1945) ; Idaho Sess. Laws c. $269, \S 66$ (e) (1947); Tenn. Pub. Acts c. $29, \S 4$ (c) (1947). But only those 
losses from such factors as cyclical unemployment, lockouts, or temporary layoffs. And workmen's compensation programs provide cash and medical benefits when workers are injured in the course of employment. ${ }^{6}$

Workers, however, are not protected against the loss of income resulting from ordinary illness and accident not connected with their jobs. This gap in the structure of social security warrants immediate attention. Each day about two million laborers are kept-from working by a temporary disability. ${ }^{7}$ The resulting wage loss to persons with incomes less than $\$ 2,500$ is almost $\$ 900$ million per year; 8 when medical expenses are added, the total loss for

registered as unemployed or those who have filed a claim for unemployment benefits are eligible. Hence a worker must be unemployed when disability strikes. And even where sickness occurs while unemployed, the worker is rendered ineligible by the availability of suitable work.

6. The most common phrase used in the state statutes is injury "arising out of and in the course of employment."

Unlike OASI and unemployment insurance, workmen's compensation is left entirely in state hands. No federal statutes, except those governing maritime workers, railroad employees and certain classes of federal employees, are concerned with work-connected disabilities. All 48 states have adopted workmen's compensation schemes. While they vary considerably in benefits, financing, and administration, they are all designed to aid the sustenance and rehabilitation of the industrially injured worker. For an excellent and comprehensive analysis of the problems inherent in this type of insurance, and how the several states have met them, see REede, AdEQUACY of WorkMren's CoMrpensation (1947).

7. Hearings before Committee on Ways and Means on H.R. 2893, 81st Cong., 1st Sess. 1092 (1949) (statement of Dr. A. J. Altmeyer, Commissioner for the Social Security Administration).

Among the more important factors determining the prevalence of disability are the following: age, sex, type of employment, and income. The latter is most significant in pointing up the need for insurance against wage loss. Work days lost per worker increase as the income scale decreases, placing the greatest burden upon lower paid laborers. The following table, taken from Falk, Sanders \& Federman, Disability Anong Gainfully Occupied Persons 9 (Social Security Board, Bureau of Research \& Statistics, Memo. No. 61, 1945), illustrates:

Annual family income and relief status. Average annual days of disability per worker.

Relief

Nonrelief

13.8

$\begin{array}{cc}\text { Under } \$ 1,000 & 9.1 \\ \$ 1,000-1,499 & 5.8 \\ 1,500 \text { to } 1,999 & 5.7 \\ 2,000 \text { to } 2,999 & 5.7 \\ 3,000 \text { to } 4,999 & 5.5 \\ 5,000 \text { and over } & 5.2\end{array}$

In addition, it has been estimated that from four to six times as many workers suffer from illness as from industrial accidents. Thus the need for disability compensation is greater than the need for workmen's compensation. DAUGHERTy, LABOR PROBLENS IN Amerucan Industry 798 (5th ed. 1941).

8. Mirlis \& Montgomery, Labor's Rusks and Social Insurance 237-8 (1938). A valuable study of the extent of illness was made in 1919 by the Illinois State Health Insurance Commission. Examination of the experience of mutual benefit associations with 
lower income families comes to some $\$ 2$ billion per year. ${ }^{2}$ The result is a decrease in purchasing power, a drain on charitable funds, ${ }^{10}$ and a lowering of health standards. ${ }^{11}$

The federal government has done little to meet this problem. Only railroad workers have any sort of disability plan.12 Though proposed health insurance plans would provide medical care to disabled persons, ${ }^{13}$ they are yet far from being a reality. And even were health insurance set up, the worker and his family would still need cash income for normal living requirements.

Nor has voluntary insurance provided an adequate solution to the disability

663,163 wage-earning members indicated that $8.8 \%$ of these workers lost $20 \%$ or more of what earnings there would have been absent some disabling iliness. REPORT OF THE Health Insurance Coararission of the State of Ilinois 151-2 (1919).

9. Mirurs \& Montgomerey, op. cit. supra note 8, at 238. See also Hcarings before Committee on Ways and Means on H.R. 4120, 74th Cong., 1st Sess. 50 (1936). The coinciding of medical expenses and wage loss heightens the seriousness of the disability problem. See Address by Mary Donlon, Chairman, New York State Workmen's Compensation Board, over radio station WNBC, Dec. 31, 1949.

Tremendous costs are also borne by employers, resulting from absenteeism, labor turnover, and selecting and training new employees or reserves. See DaugherTy, op. cit. supra note 7, at 113-114; Slichter, The Turanover of FACTORY LABOR 403-405 (1919).

10. "The public assistance rolls reflect serious financial straits to which many families have been reduced by the disability of the breadwinner. Estimates of the number of persons on the public assistance rolls whose need is attributable to disability range from 770,000 to $920,000 \ldots$ about 387,000 were children [in 1949] in 125,000 families whose fathers were disabled and who were receiving aid to dependent children. . . . The number of families receiving aid from private welfare sources has not been estimated, but they add considerably to the total. Others in need of help never come to any agency; studies made by the Bureau of Old-Age and Survivors Insurance show that many families prefer to live in want rather than turn to public aid or private charity." FEDERAL Security Agency, Soctal Security Administration, Annual Report 1949, 58 (1950). The Report does not state whether these statistics are limited to non-occupational temporary disability.

11. "... Whether or not there is social insurance, substantially the same costs exist in the form of losses of earnings from sickness, disability ... and in medical bills. When social insurance is lacking, these charges appear in the costs borne by the families concerned and the public that also foots a considerable part of the bill for relief and public welfare services, and in the loss of potential business and national income when many families are in economic distress. With social insurance, large losses suffered by a part of the population are distributed over the entire population. The relatively small but regular amounts paid out in social insurance benefits have an importance far beyond their size, both for those who receive them and for the economy as a whole." Id. at 7,8 .

12. See Federal Securtity Agency, Soctal Security Administration, Rateroad Temporary Disabieity Insurance Prograns (1949).

13. Health insurance schemes have been advocated for almost half a century. They are summarized in NICB, Conprulsory Sickness Compensation for New York State, 17-21 (1947). See also Comment, The Esscutials of An Adequate Health Program, 59 YALE L. J. 292 (1950). The main goals of these proposals have been prevention of illness and assurance of medical care, rather than compensation for wage loss. 
problem. ${ }^{14}$ Within the last decade individual medical care plans ${ }^{15}$ and individual and group insurance covering wage losses have offered a greater degree of protection than ever before. ${ }^{16}$ But most workers still cannot afford individual coverage. ${ }^{17}$ And even when they can, bad disability risks, such as women, older workers, and non-whites are often refused policies. ${ }^{13}$ Moreover, most of the relatively few group insurance plans in existence require the employee to have from 10 to 20 years of service before he becomes entitled to benefits. ${ }^{19}$ And fraternal group sickness benefit plans cover only a small minority of American workers. ${ }^{20}$ In short, too few workers have any coverage, and too many have inadequate protection.

Recognizing the widespread prevalence of disability and the inadequacy of existing protection, four states-Rhode Island, California, New Jersey and New York-recently have adopted compulsory disability insurance. ${ }^{23}$

14. "Private insurance provides some protection against earnings loss during shortterm illnesses through health and accident policies. Few families in the low and middle income groups, however, can afford to purchase private insurance contracts ... and such contracts are not available to most persons in middle or older age groups or to persons in occupations that present a risk to health." Federal Security Agency, Social Security Administration, AnNoal Report 1949, 58 (1950).

15. To the extent that medical care plans, such as Blue Cross, meet the medical expenses of a sick worker, they make a real contribution to the worker's security. But many of these plans do not include as benefits cash compensation for wage-loss. For the number of persons covered by private medical insurance see $i d$. at 24 (taking the view that even as to medical care these plans are unsatisfactory because they don't reach those who need it most and because only partial protection against medical costs is afforded).

16. See statistics for group coverage in NICB, StudIEs No. 1, BudgetrNg the Costs of ILLNESS 65 (1947).

17. Hearings, supra note 7, at 1092. See note 14 supra.

18. "Under private insurance, great care must be exercised in the selection of the risks..." Hearings, supra note 7, at 1313 (statement by Dr. Altmeyer). See also Falk, Sanders \& Federman, supra note 7, at 7; NICB, Conpulsory Sickness Compensation FOR New York State 66, Table 15 (1947). See also note 14 supra.

19. See Federal Security Agency, Soctal Security Administration, Annudul Report 1949, 58 (1950); Collective Bargatning Provistons, Emrployee Bentefit Plans, Part I-Health, Welfare, and Insurance Plans (U.S. Dept. Labor, Bureau of Labor Statistics, Sept. 1949); Selected Excerpts from Collective Bargatning Agreearents (U.S. Dep't. Labor, Bureau of Labor Statistics, March 1949 rev.).

20. See Federal Security Agency, Soctal Securtty Administration, Annual Report 1949, 58 (1950). For a description see NICB, Studies No. 1, Budgeting tHe Costs of ILlNESS 3, 16, 37 (1947).

21. R.I. Acts c. 1200 (1942) ; CaL. Gen. Laws act 8780d, $\$ \$ 150-462$ (Supp. 1947); N. J. Laws c. 110, $\$ \$ 1-33$ (1948) ; N. Y. Laws c. 600, $\$ \$ 200-242$ (1949).

In other countries, temporary disability insurance has generally been related to permanent disability health insurance. The first compulsory sickness insurance law with broad coverage, enacted in Germany in 1883, provided both medical services and cash benefits related to wage loss. By 1900 , three countries had adopted similar insurance programs. A few more countries joined in before 1914, including Great Britain. Following World War I, and especially during the 1930's there was a rapid expansion, with many South American nations adding plans. More than 50 million workers were covered in all these 
Their programs are designed to compensate workers, during a limited time, for about 50 percent of wages lost because of disability arising outside the course of employment. Like other social insurance schemes in the United States, the programs are financed by a payroll tax upon all covered employment.

These laws are likely to be looked upon by other states as examples to be copied or rejected. Fortunately, there is sufficient diversity among them to illustrate alternative programs available to a state contemplating the adoption of compulsory insurance. The existing laws will be tested by their ability to meet three underlying objectives of disability insurance: (1) to provide broad coverage and liberal eligibility requirements so that the entire labor force will be protected against disability loss; $(2)$ to extend benefits adequate to assure the disabled worker a decent minimum of economic security; and (3) to distribute the cost of insurance in the most equitable and efficient method possible.

\section{COVERAGE AND ELIGIBILITy}

\section{Coverage}

Since no one is immune from illness or injury, all workers should receive protection against the risk of disability-induced wage loss. But the statutes exempt from coverage several categories of gainfully occupied persons: the self-employed ;2 $^{22}$ those who work for employers hiring three or less per-

plans. China, India and the United States were the only important nations in which there was no government supported sickness insurance. See DaUGHERTY, Labor Problems IN AMERICAN Industry 798-9 (5th ed. 1949); Rubinow, Social Insurance 224-280 (1916); Wolfenden, The Real Meaning of Soctal Insurance 51-53, 56-60 (1932); Federal Security Agency, Temporary Disability Insurance 4 (rev. ed. 1949). Since the end of World War II, England, France, Belgium, Sweden, Denmark, and the Netherlands have enacted legislation to increase protection against risks of income loss from disability, and to remove or reduce financial obstacles to medical care. Ibid.

There are several points of similarity between the various compulsory systems: (1) Almost all plans are contributory, requiring payments from employees or the state in addition to those made by employers. (2) In a majority, the funds are built up from employee-employer contributions, with the state contributing only enough to cover administration. (3) Four kinds of benefits are commonly provided: (a) cash sickness benefit, beginning after a three or four day waiting period, extending about 26 weeks, amounting to 50 or 60 percent of customary wages and depending on a certain number of previously paid-in contributions; (b) lump sum funeral expenses equal to 30 or 40 times the basic daily wage; (c) comprehensive medical benefits, including services of physicians, hospitals and pharmacies; (d) maternity benefits. DAUGEERTY, op. cit. supra, at 798-99.

Only in the United States has unemployment insurance preceded temporary disability insurance. Temporary disability insurance in this country has differed from that in other nations perhaps because it has been considerably influenced by the unemployment insurance pattern.

22. E.g., R. I. Acts c. $1200, \S 2(7)(1942) ; i d . \$ 7(\mathrm{e})(3)$. 
sons; $;^{23}$ and employees of governmental units or non-profit organizations. ${ }^{24}$

Little justification can be found for exempting the self-employed. The primary basis for exempting them from disability insurance, as well as other social security laws, is administrative feasibility. ${ }^{25}$ Since the self-employed do not derive income from a payroll, they would have to compute profits and losses in order to determine the amount of their contribution. To require this at weekly or monthly intervals might impose a heavy burden. Moreover, the state would have to make frequent entries on thousands of individual records. But the development of practicable administrative procedures for tax collecting shows that these arguments are without force. The 1950 amendments to the Social Security Act have broadened OASI coverage to include many urban self-employed persons, ${ }^{26}$ and have devised an expedient tax return tied to income tax schedules. ${ }^{2 \pi}$ Thus instead of the tax being deducted from a weekly wage check, it can be paid annually or quarterly, simultaneously with the income tax. States could adopt a similar device. Having computed net income for federal tax purposes, the self-employed person could simply copy this computation for the state.

Discrimination against those who work for employers hiring three or less persons also has no reasonable basis. ${ }^{28}$ Advocates of the small-shop exemp-

23. E.g., N. Y. Laws c. 600, §202(1) (1949). But see CaL. Gen. Laws act 8780d, $\$ \$ 8.5,151$ (Supp. 1947) (employers of one or more are included).

24. E.g., N. Y. Laws c. $600, \S 201(6)$ (1949).

25. See, e.g., Falk, Reed \& Sanders, Some Problems in the Formulation of a Disability Insurance Program, 6 LAw \& Contearp. Pros. 645 (1939).

26. Pub. L. No. 734, Chap. 809 (1950), U. S. Cone Cong. SeRv. 561 (1950).

Their coverage is made compulsory. "The history of voluntary social insurance in other countries indicates definitely that only a very small proportion of all eligible individuals actually elect to participate. Moreover, the ones who do elect to participate are usually not those of average or below average income. In addition, voluntary coverage would probably attract almost exclusively people who are already aged and others who can foresee a large possible return for their contributions; as a result, the program would be faced with adverse selection of risks and a serious drain on the . . fund." SEN. REP. No. 1669 (May 17, 1950), cited in U. S. Cone Cong. Serv., 81st Cong., 2nd Sess. 3287, 3299 (1950).

27. "The fact that almost all full-time and a large proportion of part-time selfemployed persons have for the last few years been required to file income-tax returns has radically changed the outlook for extending coverage to this group. It has been demonstrated that income reports can be obtained from the great majority of self-employed, and it is now apparent that the coverage of the insurance system can be extended to them by tying in a self-supporting system for social insurance with the income tax. Certain items now reported for income-tax purposes can be used as the contribution base for old-age and survivor's insurance and entered on a social-security report form. In the main, these items are net income from a business, profession, or farm (schedule $C$ of the Federal income-tax return), and from partnerships, syndicates, etc. (schedule E)." The Reports of the Advisory Council on Social Security to the Senate Conmittee on Fintance, Sen. Doc. No. 208, 80th Cong., 2nd Sess. 15 (1948). See also Packer \& Liebowitz, Coverage of the Self-Employed Under the Old-Age and Survivors Insurance, 36 CALrF. L. Rev. 61 (1948).

28. "Continuation of the size-of-firm exclusion ... cannot be justified . . . on the ground of administrative difficulty. Nor can the exclusion be justified on the ground 
tion claim that it eliminates the handling of thousands of firms which otherwise would overburden administration of the program. But California has demonstrated that small shops can be effectively covered without administrative difficulty. ${ }^{29}$ And the seventeen states which have discontinued this exemption under unemployment insurance likewise report beneficial results. ${ }^{30}$ Elimination of the small-shop exemption would also avoid the unfairness resulting from imposing different tax liability on competing firms of slightly different size. ${ }^{31}$

The exemption of employees of governmental units and non-profit organizations is a carryover from the Social Security law. These exemptions were written into that statute presumably because of Constitutional barriers against federal taxation of certain state government agencies and a long-established federal policy against taxing charitable institutions. ${ }^{32}$ An individual state, however, could cover its own employees by contributing out of general revenues what would normally be the employer's share. It could also require contributions by its employees. And states could extend coverage to employees of non-profit units by imposing a payroll tax directly on such organizations.

that the services performed by workers in small firms are different from the services performed by workers in larger firms. This exclusion is based solely on size-of-firm and not on nature of employment. Their services would be covered if performed in a larger firm." Report of the Technical Staff of the House Committee on Ways and Means, cited in, Report of the New York State Advisory Council on Placenent and UnearployMENT INSURANCE FOR THE YEAR 1947, 3. All employers regardless of size are within the provisions of OASI. They are required to prepare quarterly reports, and make quarterly contributions and withholding payments. "That system [OASI] has found coverage of small employers to be administratively feasible." Id. at 2 .

29. For the period May 21, 1946 to March 31, 1948 California spent a little more than half of the monies available for administration, indicating little, if any, difficulty in handling small firms. Federal Security Agency, California Disabitity Insurance Program 39, Table 4 (1948).

30. A study of experience in 13 of these states revealed the following information: Reports add up to evidence overwhelmingly in favor of full coverage. Limited coverage is exposed as an administrative, a social, and an economic handicap. A consensus revealed: "Administrative difficulties are overshadowed by administrative advantages." "All states are in agreement in reporting no unwholesome economic effect on small firms which can be charged to unemployment-insurance coverage. On the contrary, several states emphatically point to beneficial economic results." REPORT of THE NEW York State Adyisory Council on Placement and Unemployment Insurance for THE YEAR 1947, $2,3$.

The 13 states reporting represent both large and small, whether based on population or geography, and include predominantly agricultural as well as industrial commonwealths. E.g., Arkansas, Delaware, Idaho, Massachusetts, Nevada, Pennsylvania.

31. Although the taxation phase of disability insurance will be discussed more fully at pages 666-67 infra, it is appropriate to mention here that some states require contributions from employers. This tax cost is ultimately reflected in price. Hence a producer not required to contribute enjoys a distinct price advantage through mere fortuity rather than wise business judgment.

32. Internal Revenue Code $\$ 101(6)$. And see Graves v. New York ex rel. O'Keefe, 306 U. S. 466 (1939); New York v. United States, 326 U. S. 572 (1946). 
The exemption from taxation of these groups is based on the notion that they should be financially unhampered to devote all their monies to charitable, religious, and educational ends. While these aims are socially desirable, so is the provision of disability benefits. In the event, however, that states are unwilling to extend mandatory coverage in these areas, coverage could be extended on a voluntary basis similar to that recently accomplished under the 1950 amendments to OASI. ${ }^{33}$

\section{Eligibility}

Qualifying Earnings or Employment. Since the purpose of disability insurance is to protect workers from income loss, only those gainfully employed, or those unemployed but seeking work, are made eligible for benefits. Among the four states there are two criteria for determining whether a claimant is an active member of the labor force. One is a wage test. The claimant must show minimum earnings varying from $\$ 100$ to $\$ 600$ during a base year before he became disabled. ${ }^{34}$ In contrast, the second test requires only that the worker

33. The 1950 Amendments to the Social Security Act, Pub. L. No. 734, Chap. 809, 81st Cong., 2nd Sess. § 218 (Aug. 28, 1950), U. S. Code Cong. SeRv. 561, 596-99 (1950) made provision for covering under OASI the following workers:

Federal employees: Federal employees are covered unless their service is already covered by a retirement system established by a law of the United States. There are other "unless" clauses, but of minor importance.

Employees of transportation systems operated by a state or political subdivision: If since 1936 the state or political subdivision has acquired or acquires a transportation system from private ownership after 1936 all employees will be covered unless the state or subdivision has a constitutionally protected retirement system for services performed in connection with that transportation system.

State and local employees: All state and local government employment which is not under an existing retirement system could be covered through voluntary agreements between the states and the Federal Security Administrator. Voluntary agreements must be made with respect to specific coverage groups, i.e., all the employees of a state or city, or, separate coverage groups of employees engaged in the performance of single proprietary functions. These federal-state agreements can be terminated on two years notice, but only after they have been in effect for five years. While the agreement is in effect, the Federal Government can enforce the state's duty to pay the required contributions by deducting the defaulted amount from payments otherwise due to the states under other titles of the Social Security Act (chiefly federal grants for public assistance).

Employecs of religious, charitable, and certain other non-profit organizations: Service performed for an organization exempt from income tax under $\$ 101(6)$ of the Internal Revenue Code (non-profit religious, charitable and educational institutions) is excluded from OASI coverage unless the organization files a certificate expressing its desire to be covered. The certificate must contain the assent of at least two-thirds of its employees. Where the certificate is valid, both employer and employees are subject to such taxes in the same manner as a private employer and his employees. The organization may terminate coverage only after eight years and with two years advance notice-making a minimum of ten years coverage.

34. CaL. Gen. Laws act 8780d, $\$ \$ 6(q), 205(c)$ (Supp. 1947) (\$300) ; N. J. Laws, 1948 , c. $110, \S \S 17,20$ (30 times weekly benefit amount); R. I. Acts, 1949, c. 2206, § 3(12) $(\$ 100)$. 
have been employed for four consecutive weeks prior to the commencement of disability $;^{35}$ or, in the case of an unemployed worker, that except for the disability, he be qualified for unemployment compensation. ${ }^{36}$

Both tests are likely to render ineligible some workers. Emphasis on wages might operate to disqualify lower paid workers, seasonal employees, and new recruits to the labor force..$^{37}$ Similarly, under an employment test workers obtaining jobs for the first time or returning to work after a lay-off will be ineligible until they have worked the required number of weeks. Any test based on previous wages or employment is bound to raise these problems. But the inequities can be minimized by keeping the requirements low, such as minimum earnings of $\$ 100$ a year under a wage test or a four weeks' period under an employment test.

Disqualifying Income. Under existing statutes income received by a disabled worker ordinarily affects his right to benefits. In California and New York the worker may receive both wages and disability benefits, but they must not total more than his benefits alone would otherwise provide. ${ }^{38}$ Rhode Island, on the other hand, allows complete disability benefits even when full wages are paid. ${ }^{39} \mathrm{New}$ Jersey, adopting a mid-way position, restricts the total which the worker can receive to the amount of regular weekly wages earned prior to disability. ${ }^{40}$

These provisions are identical with the respective states' unemployment insurance laws.

"Base period" is defined in the case of Rhode Island, for example, as the calendar year immediately preceding the first Sunday in April of any year. R. I. Acts, 1949, c. $2206, \S 3(12)$. This means that each year a worker has a different base year from the one he had the previous year.

35. See N. Y. Laws, 1949, c. 600. $\S \$ 203,204$.

36. Id. $\$ \S 207(1)$ (2). Relating eligibility of the disabled unemployed back to the qualifications of unemployment insurance makes the wage test relevant again. But New York has established an additional category of qualifications for unemployed claimants. If the claimant did not earn unemployment insurance qualifying wages, he may still be eligible for disability benefits if he earned $\$ 13$ in covered employment in each of 20 out of the 30 weeks preceding the last day worked. Ibid.

37. ". . . eligibility for [unemployment insurance] benefits usually specifies earnings equal to some multiple (usually 30 times) of the benefit amount. Thus, the increase in the minimum benefit amount in California to $\$ 10$ necessitates earnings of at least $\$ 300$ [during a base period] which, it is estimated, will render ineligible 20 percent of formerly eligible claimants." UnEmployanent Compensation Contributions, Benefits and Reserves, Social Security Board, Emiployanent Security Memo. No. 5, 17 (1940).

38. CaL. Gen. Laws act 8780 d, $\$ 208$ (Supp. 1947) ; N. Y. Laws, 1949, c. 600, $\S$ $205(6), 206$.

See also discussion in Note, Legislative Medicine for the Sick Worker, 2 Stan. L. REv. 345, 355, 356 (1950).

39. R. I. Acts, 1943, c. $1367, \S \S 2$ (1) (13) (14) (15). See also BuREAU of EnIPLoYMent Security, Comparison of Temporary Disabitity Insurance Laws, Decenrber 1, 1949, 4 (U. S. Dep't Labor); Studies in Disability Insurance 3 (N. Y. Dep't Labor 1949).

40. N. J. Laws, 1948 , c. $110, \S \S 6,15(f)$. 
Of these provisions, duplication limited to the amount of previous wages seems preferable. When the employer agrees to continue wages during disability, he is granting in effect a wage increase which should be permitted to supplement the state-created benefit. ${ }^{41}$ But limiting the total to regular wages is advisable to reduce malingering. Temptation may be too great if an employee can receive more income by remaining idle than by working.

A worker entitled to workmen's compensation benefits is ineligible for disability benefits for the same injury in all the states except Rhode Island. ${ }^{42}$ Rhode Island pays benefits from both programs, provided the combined benefits do not exceed 85 per cent of the worker's average wage on his last job. ${ }^{43}$ This duplication is undesirable. The function of disability insurance is to fill the gap in the worker's security by protecting him from non-occupational injury and illness. He is already covered for work-connected disability. If workmen's compensation benefits are adequate, duplication is a waste of funds. And if benefits are inadequate the remedy is to liberalize them within the workmen's compensation program itself, not to subsidize that program from disability insurance. For one thing, the two programs may be financed from different sources. ${ }^{44}$ Furthermore, workmen's compensation programs,

41. Some employers have established, as a result of their own initiative or through collective bargaining, formal wage-continuation plans. Others, with no formal plans, continue to pay wages to sick employees anyway. Often, these payments amount to a fixed percentage of regular weekly wages.

The California and New York rule, reducing state benefits to the difference between the employer's continuing wage and the appropriate benefit amount, discourages such wage-continuance plans. For whether or not the employer maintains wages, his employee will receive the same number of dollars. Hence why not allow the insurance, for which the employer helps pay anyway, supply the full benefit?

42. There should be one exception to this disqualification rule. "Workmen's compensation payments for some other incapacity, such as a permanent physical impairment, do not involve duplication. Consequently, receipt of permanent partial or total disability benefits under workmen's compensation for a disability of prior origin should not affect a claimant's right to temporary disability insurance. The former are compensation for decrease in earning power, the 1atter, for current loss of earnings. ..." FEDERAL SECuRITY Agency, Temporary Disability Insurance 24 (rev. ed. 1949).

Often there is some difficulty in determining whether a particular injury or disease is work-connected. And delays are not infrequently encountered in workmen's compensation proceedings. During this period the worker receives no benefit payments. Here, disability insurance can fill the gap by extending benefits to the claimant until the workmen's compensation issue is settled. If the worker is not entitled to workmen's compensation, he will continue under disability insurance. If, however, he is entitled, then disability benefits cease and workmen's compensation commences. The disability insurance fund can then be reimbursed by the workmen's compensation fund. Such is the law of California and New York. See, e.g., N. Y. Laws, 1949, c. 600, §206(2).

43. R. I. Laws, 1949 , c. 2194, § $5(3)$.

44. Under most workmen's compensation programs employers bear the entire cost. But in disability insurance, contributions are either shared by employers and employees, or are made entirely by employees.

In computing the costs of a disability program if disability insurance benefits are to be paid simultaneously with workmen's compensation benefits, actuarial data on state- 
unlike the present cash disability insurance schemes, provide medical services as well as compensation for lost wages. As long as this difference continues, all benefits for workers injured on the job should be disbursed through the workmen's compensation system, in order to insure proper allocation of funds between compensation for wage loss and medical expenses.

Extent of Disability. A disability is compensable under the existing laws when the ciaimant is physically unable to perform the regular duties of employment at his most recent job. ${ }^{45}$ There has been suggested a more stringent test of disability: total incapacity to perform any remunerative work which the employee is qualified to do. ${ }^{48}$ But such a test would interject unnecessarily complicated issues of the type of work a disabled claimant is capable of performing. Moreover, although the claimant may be physically able to perform lighter work, he may not be able to find a suitable job for a temporary period. Thus under the proposed test, he would receive neither disability benefits nor wages. ${ }^{47}$

In addition to requiring a certain degree of disability, the statutes impose a waiting period of seven days from the beginning of disability before payments can be made. ${ }^{48}$ Some waiting period is justifiable because it will remove incentive to malingering and because the volume of very short-lived disabilities is too great for effective administration. ${ }^{49}$ The period, however, should

wide disability risks must include work-connected injuries and illness. Otherwise the disability fund would be making benefit payments without corresponding contributions to it. Whether Rhode Island overlooked this point is not known. But one reason for the threatened insolvency of that state's fund was frequent payment of disability and workmen's compensation benefits for the same mishap. MUNTz, Growtr ANd TrENds IN Soctal Security, NICB, Studies No. 6, 92 (1949).

45. See, e.g., N. Y. Laws, 1949 , c. $600, \S 201(8)$ : “'Disability' during employment means the inability of an employee, as a result of injury or sickness not arising out of and in the course of employment, to perform the regular duties of his employment or the duties of another employment which his employer may offer him at his regular wages and which his injury or sickness does not prevent him from performing." In the case of a disabled unemployed: "Disability" . . . means the inability of an employee, . . . to perform the duties of any employment for which he is reasonably qualified by training and experience." Ibid.

46. See Federal Security Agency, Tearporary Disability Insurance 7, 8 (rev. ed. 1949).

47. For an illustration of this effect see ibid.

48. A11 the existing laws have a seven day waiting period with one exception for hospitalized claimants in California (see note 50 infra). See, e.g., CAL. GEN. Laws act 8780d, §205(b) (1947); N. Y. Laws, 1949, c. 600, \$\$ 204(1), 207 (2).

Several states dispense with the waiting period requirement when a subsequent disability related to the initial malady occurs within a specified period after the first illness. The purpose of this waiver is to prevent hardship on a claimant who is, in effect, suffering from one disability. Cal. Stäts., 1949, c. 1441, $\$ 205$ (b) (two weeks); N. Y. Laws, 1949 , c. $600, \S 204$ (1) (three months). Only one waiting period a year is required by Rhode Island. R. I. Acts, 1942, c. 1200, $\$ 6(2)$.

49. A survey shows that about $50 \%$ of all disabilities last less than seven days. Gafafer (editor), Mranual of Industrial Hygiene and Medical Service in War 
not be too long-certainly no longer than a week. Many workers will probably be able to tide themselves over a brief period of income loss. But they may find it impossible to save enough for family necessities over a long span, especially when medicines and doctor's services are required.

California has recently amended its statute to eliminate any waiting period when a claimant is hospitalized. ${ }^{50}$ Other states might well follow suit. Since hospitalization often means expensive medical services, the personal savings of a hospitalized worker may be insufficient to defray costs of even seven days' illness. Furthermore, hospitalization generally follows a severe disability. This, coupled with close hospital supervision, may make malingering more difficult. It also means that many hospitalized workers are incapacitated for more than seven days. As a result, no administrative problem would be presented in such cases, since a claim for benefits would ordinarily be filed after the eighth day anyway.

\section{BeNEFITS}

The benefits provided by disability insurance are capable of fulfilling two functions: they may indemnify the disabled breadwinner when normal income ceases; and they may aid rehabilitation by providing medical diagnosis and therapy for the disabling illness or injury. With one slight exception, state programs provide only indemnification benefits.

\section{Indemnification}

Determination of the amount of the cash benefit requires a compromise between two often conflicting considerations. The purpose of disability insurance is to maintain the worker during interruption of earnings with as little as possible alteration of his usual standard of living. ${ }^{51}$ Therefore benefits

INDUSTRIES 436 (1943). On the salutary administrative effect of a waiting period, see Federal Security Agency, Temporary Disability Insurance 16 (rev. ed. 1949).

50. Ca1. Stats., 1949, c. 951, § 209.

51. Perhaps the most extreme expression of this view is represented by the Beveridge plan. The essential thrust of Beveridge's philosophy is to insure the maintenance of the population at a subsistence level. The benefit is deliberately based upon a calculated minimum subsistence budget. See SIR Whitam Bevermge, Soctal Insurance and Allied Services 14, 15, 54-55, 76-90 (1942) ; PINK, FrendoM From FEAR 36, 40 (1944); Burns, Unemployment Compensation and Socio-Economic Objectives, 55 YALE L. J. 1 (1945).

At the other extreme are the American compensation acts, where indemnity for loss, not subsistence income is the keynote. Benefits are based upon a scale of normal wages for the individual. Usually $50 \%$ of those wages constitute the benefit amount, with minimum and maximum limits set, and without regard to wage levels. Since the maximum benefit is a small amount, workers without high wages will receive much less than $50 \%$ of their wages. The modern laws, however, are gradually leaning toward the maintenance theory. Witness the Washington and Wyoming compensation laws where fixed amounts are paid, depending upon the number of dependents. For an analysis of factors occasioning the trend toward maintenance, see Burns, supra, at 16; Burns, Social Insurance in Evolution, 34 Axr. Econ. Rev. Supp. No. 1, 199 (1944). 
should be a substantial proportion of wages. On the other hand, benefits which approximate the wage earner's regular income may reduce his incentive to return to work. Therefore, sufficient margin must be kept between benefits and what can be earned in employment. ${ }^{52}$

Present statutes attempt a compromise by fixing minimum and maximum benefit limits. To assure the disabled worker a maintenance income, each of the laws prescribes minimum weekly cash benefits- $\$ 9$ in New Jersey, ${ }^{63}$ $\$ 10$ under the other three laws. ${ }^{54}$ Maximum benefits are set at a low figure to discourage malingering and to keep down the cost of the program. Thus New Jersey limits the benefit amount to $\$ 22$, ,5 while Rhode Island and California, specify $\$ 25,{ }^{56}$ and New York $\$ 26.57$ Within the minimum and maximum limits the worker's weekly benefit rate varies with the amount of wages earned during a preceding base period. ${ }^{58}$

The attempted compromise has resulted in benefits which fall short of adequately indemnifying workers. Existing laws fail to recognize that the hardships of disability fall on the family, not merely on the individual. A satisfactory minimum income for a family of four is approximately $\$ 3,000$ per year, or nearly $\$ 60$ a week. ${ }^{59}$ And such a family has but a negligible

52. Malingering always has been a major fear of social insurance planners. They abhor the circumstances which may lead to a lazy reliance upon government for support. Hence two safeguards are established: small benefits in proportion to wages, and eligibility provisions which must give assurance that the claimant is normally part of the labor force.

53. N. J. Laws, 1948, c. 110 , $\$ 14,16$.

54. Caz. Gen. Laws act 8780 d, $\$ \S 54,203$ (1947) ; Cal. Stats., 1949, c. 1441, §53; R. I. Acts, 1942, c. $1200, \S 5(4)$; R. I. Acts, 1949, c. 2194, $\S \S 5(2)(3)$.

55. N. J. Laws, 1948, c. $110, \S \S 14,16$.

56. R. I. Acts, 1949 , c. 2194 , $\S 5$ (2) (3) ; Cal. Stats., 1949, c. 1441, §§ 53, 54.

57. N. Y. Laws, 1949, c. $600, \S 204(2)$.

58. The amount of the benefit depends on the claimant's earnings during a specified calendar year or the highest quarter thereof prior to the time the claim is filed. See, e.g., Cal. Stats., 1949, c. 1441, §54. But cf. N. Y. Laws, 1949, c. 600, \$§ 204(2), 201(12): weekly compensation equals half the claimant's average weekly wage during the last eight weeks of employment preceding the disability.

The following excerpt from the California' statute illustrates how benefits are related to past earnings :

\begin{tabular}{|c|c|c|}
\hline $\begin{array}{l}\text { Amount of wages in } \\
\text { highest quarter of } \\
\text { base period }\end{array}$ & & $\begin{array}{l}\text { Weekly benefit } \\
\text { amount }\end{array}$ \\
\hline$\$ 75.00-\$ 199.99$ & $\ldots \ldots \ldots$ & $\$ 10$ \\
\hline $240.00-259.99$ & $\ldots \ldots \ldots$ & 13 \\
\hline $300.00-319.99$ & $\ldots \ldots \ldots \ldots \ldots \ldots \ldots \ldots \ldots \ldots \ldots \ldots \ldots$ & 16 \\
\hline $380.00-419.99$ & $\ldots \ldots \ldots \ldots \ldots$ & 20 \\
\hline $500.00-539.99$ & $\ldots \ldots \ldots \ldots \ldots \ldots \ldots \ldots \ldots \ldots \ldots \ldots \ldots \ldots$ & 23 \\
\hline 580.00 and over & $\ldots \ldots \ldots \ldots$ & 25 \\
\hline
\end{tabular}

59. The median income of families in the United States in 1947 was $\$ 3,031$. However, the median for families with four or more children was $\$ 2,731$ in the same year. It cost city families with four children from $\$ 3,004$ to $\$ 3,458$, depending on price levels in different cities, to purchase the most modest living. Federal Security Agency, Soctar. Security Administration, Annual Report 1949, 148-149 (1950). 
margin of savings. ${ }^{60}$ Yet the highest disability benefit rate is $\$ 26$ a week. ${ }^{61}$ Moreover, since benefits are in proportion to past earnings, the lower paid workers, who have fewer savings, receive less than $\$ 26 .{ }^{62}$

The inadequacy of present benefits can be overcome by including an allowance for the disabled worker's dependents. ${ }^{63}$ Three dollars weekly for each child, for example, and from $\$ 5$ to $\$ 10$ for a spouse would do much to relieve the financial hardships engendered by disability. ${ }^{64}$ Such dependents' allowances are entirely feasible under disability programs. They have already

60. "One evidence of the difficulties families have been having in meeting the mounting cost of living is the fact that early in 1949, 29 percent of all United States families had no liquid assets. In 1948, 3 in every 10 families spent more than they received that year." Id. at 149. See also Ellickson, Labor's Demand For Real Employment Security, 55 Y ALE L. J. 253, 255 (1945).

61. I.e., New York State. See note 57 supra.

62. See note 58 supra. Benefits are in proportion to past earnings in unemployment insurance also. Of this it was said: "For extension of coverage is of no advantage to low paid groups ... unless the benefits make at least a substantial contribution to living expenses, and this can certainly not be assured so long as the present automatic relationship to past wages is retained." Burns, Unemployment Compensation and Socio-Economic Objectives, 55 Yale L. J. 1, 16 (1945). In addition, "[w] eekly benefit payments at best run only about 50 to 60 percent of wages while, for the higher wage workers, weekly benefits may be as low as a third or a quarter of wages. An extremely rough calculation made in the Bureau of Employment Security indicates that for the year 1944 the average benefits paid would have been about one-third of average wages in the states." Clague, The Economics of Unemployment Compensation, 55 YaLE L. J. 53 (1945). See also EMrpoyarent Security Memo. No. 5, Unemployaent Compensation, Contributions, BeneFITS AND RESERVES 17 (1940). During the third quarter of 1949, of the 16,373 claims paid by the California state disability fund 1,595 were $\$ 20$ or less. This figure includes both men and women. State of California, Dep't of Employment Report 1031 \#5, table 3 (1949).

63. "Present benefit rates are governed solely by prior earnings. One claimant gets more simply because he was fortunate enough to earn more in the past though he has only himself to provide for, while another who has a family to support and for whom unemployment is immeasurably the greater disaster gets less because he earned less, though that in itself makes his position the more precarious. The monies which we provide for unemployment insurance are social funds and must be distributed not just to increase the general income of the claimants but to meet the underlying social need. So that unemployment insurance in our State may deal with insecurity realistically and so that the funds may be spent most effectively and most economically, our formula should differentiate between those who have only themselves to look after and those with family responsibilities." Report of tHe New York State Advisory CouncIL oN Placement and Unemiployarent Insurance for the Year 1947, 5-6. The need may be even greater in cases of disability because, in addition to normal basic necessities, medical services often must be purchased.

64. The payment of dependents' allowances meets, to some extent, the increased cost of basic necessities for larger-sized families. Actually, a $\$ 3$ weekly benefit for dependent children would be very modest. Each additional family member increases, in 34 cities, the total weekly cost of goods and services for a family by about $\$ 10$. For example, in Detroit, basic living costs for a single person is estimated at $\$ 26.31$, while for a family of two it becomes $\$ 37.23$, for a family of three, $\$ 47.87$, and for four, $\$ 57.19$. 11 Social Security Bull. No. 4, 9 (Apr. 1948). See generally id. at 3-9. 
worked successfully in five states with unemployment insurance, ${ }^{65}$ in ten states with workmen's compensation, ${ }^{66}$ and on a national scale with the old age insurance system. ${ }^{67}$

Duration of weekly payments is limited by two factors. Total benefits available to any claimant during a year's period are directly proportional to his previous income during a base year. ${ }^{08}$ When weekly benefit payments exhaust this total, they cease. In any event payments are restricted to a maximum of twenty-six weeks per year. ${ }^{69}$ Thus lower paid workers will have fewer compensable weeks than their higher salaried brethren. ${ }^{70}$ Because

65. Connecticut, District of Columbia, Massachusetts, Michigan and Nevada.

66. Ten states, including Massachusetts, provide dependents' allowances during periods of temporary total disability. "Similar recognition of social need is to be found in the New York workmen's compensation act in the provision which it makes for widows and orphans of those killed in industrial accidents." REPORT OF THE NEW York State Advisory Council on Placement and Unemployasent Insurance for THE YEAR 1947, 8.

67. OASI increases the monthly annuity in cases where dependents exist. For example, in the fiscal year ending June, 1949, the following average benefits were paid to claimants :

\begin{tabular}{|c|c|}
\hline $\begin{array}{c}\text { Status } \\
\text { Retired }\end{array}$ & Benefit \\
\hline Worker with no dependents $\ldots \ldots \ldots \ldots \ldots \ldots \ldots \ldots$ & $\$ 26.20$ \\
\hline Worker with wife $\ldots \ldots \ldots \ldots \ldots \ldots \ldots \ldots \ldots$ & 41.00 \\
\hline $\begin{array}{l}\text { Survivor families } \\
\text { Aged widow } \ldots \ldots \ldots \ldots \ldots \ldots \ldots \ldots \ldots \ldots \ldots \ldots \ldots \\
\text { Widow with one child } \ldots \ldots \ldots \ldots \ldots \ldots \ldots \ldots \ldots\end{array}$ & $\begin{array}{r}\$ 20.70 \\
36.30\end{array}$ \\
\hline
\end{tabular}

Federal Security Agency, Social Security Administration, Annual Report 1949, 28 (1950).

68. See e.g., R. I. Acts, 1949, c. 2194, §5(2) Table A. To illustrate, following is an excerpt from the total benefits table in the Rhode Island statute:

\begin{tabular}{|c|c|c|}
\hline $\begin{array}{l}\text { Total Wages in Base } \\
\$ 100.00-199.99\end{array}$ & $\begin{array}{l}\text { Perioda } \\
\text { P. }\end{array}$ & $\begin{array}{l}\text { Benefit Oredits } \\
\$ 52.00\end{array}$ \\
\hline $200.00-299.99$ & & 78.00 \\
\hline $900.00-999.99$ & $\bullet$ & 260.00 \\
\hline $1500.00-1599.99$ & . & 416.00 \\
\hline $2300.00-2399.99$ & ${ }_{1} \ldots \ldots \ldots \ldots \ldots \ldots \ldots \ldots \ldots$ & 624.00 \\
\hline $2400.00-$ and over & note 34 supre. & 650.00 \\
\hline
\end{tabular}

New York has an entirely different method. It uniformly limits duration to a maximum of 13 weeks, with no regard to previous income. N. Y. Laws, 1949, c. 600, $\$ 205$ (1).

69. See, e.g., N. J. Laws, 1948 , c. $110, \S 15(\mathrm{a})$. New York is an exception. Its maximum is 13 weeks. See note 68 supra.

70. The following table indicates how a worker would fare under the Rhode Island Statute :

\begin{tabular}{|c|c|c|c|}
\hline $\begin{array}{l}\text { Wages Earned } \\
\text { in Base Year }\end{array}$ & $\begin{array}{c}\text { Total } \\
\text { Benefits }\end{array}$ & $\begin{array}{l}\text { Weekly } \\
\text { Benefita }\end{array}$ & Duration of \\
\hline$\$ 100 \ldots \ldots \ldots \ldots \ldots$ & $\$ 52$ & $\$ 10$ & $5+$ weeks \\
\hline $200 \ldots \ldots \ldots \ldots \ldots$ & 78 & 10 & $7+$ \\
\hline $1,000 \ldots \ldots \ldots \ldots \ldots$ & 286 & 15 & 19 \\
\hline $2,000 \ldots \ldots \ldots \ldots \ldots$ & 546 & 25 & 21 \\
\hline 2,400 or over $\ldots \ldots \ldots$ & 650 & 25 & 26 \\
\hline
\end{tabular}


the former suffer more frequent and prolonged disabilities, ${ }^{71}$ and have less resources to begin with, such a limitation appears unwise. All workers, regardless of their past wages, should receive benefits for twenty-six weeks per year if their disabilities last that long. ${ }^{\mathbf{7 2}}$

\section{Rehabilitation}

Without health insurance there is generally no way for a disabled worker to secure adequate medical care. He must rely on charity, go into debt, or forego medical treatment at the risk of aggravating his disability.

The assumptions that underlie disability programs warrant provision for medical benefits. ${ }^{73}$ The statutes assume an illness or accident necessitating at least some medical attention, since they require certification by a doctor. ${ }^{74}$ Moreover, many instances of disability for seven days, the required waiting period, need extensive professional therapy. By providing cash benefits the statutes presuppose that the worker and his family are in dire economic straits. Furthermore, temporary disability is the key-note of the system. Quick recovery and early return to work are contemplated. ${ }^{75}$ If adequate

In New York this could not occur, because a total benefits figure is not used. In that State the weekly benefit, see note 58 supra, must be paid up to a maximum of 13 weeks to anyone whose disability lasts that long.

71. See note 7 supra.

72. Though arbitrary, twenty-six weeks seems reasonable. The purpose of disability insurance is to protect individuals from the economic hardships of temporary sickness, not of permanent or extended ill-health. Although permanent impairment of earning power also means economic disaster for the ordinary wage earner, he can be better protected under an amendment to OASI. Withdrawal from the labor market because of total incapacitation is in effect premature superannuation and more closely related to old age than to the relatively short disability-induced lay-off.

Thirty countries connect permanent disability insurance with old age and survivors' insurance. Since 1940, the Social Security Administration has consistently recommended establishment of extended disability insurance with old age insurance. McCamman, Disability Protection Under Public Programs, 11 Soctal Security Bulc. No. 6, 4-13 (June 1948) ; Federal Security Agency, Temporary Disability Insurance 1-2 (rev. ed. 1949). A new title was added to OASI by the 1950 Amendments, providing grants to states for aid to the permanently and totally disabled. Pub. L. No. 734, 81st Cong., 2d Sess. $\$ 351$ (Aug. 28, 1950), U. S. Code Cong. Serv. 634-637 (1950). This is by no means an attempt to establish comprehensive extended disability insurance. For example, a person whose disability is expected to incapacitate him for two years would not be entitled to aid. Disability must not only be total, but permanent.

73. As to the type of medical services that could be rendered see note 94 infra. Medical benefits provided in Workmen's Compensation are explained in REEDE, ADEQUACY of Workaren's Conpensation 156-166 (1947). See also the discussion of the Ives, Austin, Halpern and Condon bills in New York calling for a health insurance program in that State, in NICB, Compulsory Sickness Comipensation for New York State 50-54, 152-161 (1947).

74. The nature and probable length of the disability must be certified by a doctor. See, e.g., N. J. Laws, 1948, c. 110, \$7.

75. Two factors are evidence of this: a) Duration of payments is limited to 26 weeks (13 weeks in New York); b) Dollar amount of benefits is kept low to minimize malingering. 
diagnosis and therapy at an early stage of disability are neglected, either the period of disability is likely to be extended or the laborer may resume normal duties before he has fully recuperated, thus permanently impairing his health.

An initial forward step has been taken by California. That state now provides immediate reimbursement of hospital expenses up to $\$ 8$ a day for 12 days. ${ }^{78}$ Other states have not followed its example. Perhaps as they come to realize that medical benefits for the worker are not only essential, but entirely feasible, they will integrate them into the present systems.

\section{Financing the Plan}

There are two available methods of financing disability plans. A payroll tax may be imposed on covered employment; or funds may be secured from the general revenues of the state, so that all members of the community, whether covered or not, pay the cost.

The existing statutes have relied exclusively on the payroll tax. California and Rhode Island finance their programs solely by employee contributions of one percent of yearly wages up to $\$ 3,000.77$ New York and New Jersey require joint contributions from employers and employees ${ }^{78}$ which also total one percent of payrolls. ${ }^{79}$

76. Cal. Stats., 1949, c. 951, §209.

77. CaL. GEN. Laws act $8780, \S \S 44,400$ (1947); R. I. Acts, 1942 , c. $1200, \S 4(1)$. These states were among the few that levied one percent payroll tax on employees for purposes of unemployment insurance. Since the unemployment insurance funds in those states contained considerable reserves, the one percent tax on employees was diverted to disability insurance programs. In effect, then, no new tax was levied to establish the disability program.

78. In New Jersey, employees sustain three-quarters of this $1 \%$ contribution. Employers pay from .1 to $.75 \%$ of payrolls, depending on merit rating, see pages 66465 infra, and the condition of the insurance fund. N.J. Laws, 1948, c. 109, $\$$ 1(d) (e). In New York, the maximum employee tax is $.50 \%$ of payrolls, instead of $.75 \%$, and employers are required to contribute whatever additional cost is necessary under their plans. N.Y. Laws, 1949 , c. $600, \S \S 209(3), 210(2)$.

79. One percent of covered payrolls is generally considered sufficient to cover disability benefits as now constituted. Although Rhode Island's program came dangerously close to insolvency in 1946, see notes 38 and 45 supra, experience in other states indicates that $1 \%$ is more than enough. California's record for example proves that $1 \%$ may be an overestimate; during the fiscal year ending June 30,1948, benefit costs were $0.41 \%$ of payrolls. Federal Security Agency, Social Security Administration, Annual. REPORT 1948, 139 (1949). In a two year period California revenues amounted to $\$ 90.6$ million, while benefit payments totaled $\$ 22.7$ million and administrative costs were $\$ 2.5$ million. Federal Security Agency, Californta Disability Insurance Program 18 (1948). Despite this favorable experience, a state embarking on a disability insurance program should not specify contributions at less than $1 \%$ of wages. Part of the fund must be reserved for such contingencies as epidemic or unemployment. In addition, conditions in California may not exist elsewhere. The health record, adequacy of medical facilities, level of income, age and sex of the community, and costs of living-all factors which ultimately influence the cost of disability insurance-vary considerably from state to state. 
Where a state relies either partially or exclusively on a payroll tax, participation by both employers and employees seems advisable. Employers benefit considerably from disability insurance. By relieving workers of financial difficulties resulting from sickness, the programs tend to aid workers' recovery and thereby reduce absenteeism and cut employers' costs. ${ }^{80}$ The programs also help to improve the general level of health within the state. The cash payments further benefit employers by maintaining purchasing power. Finally, most of the employers' burden often can be shifted to the consuming public so that ultimately the entire community participates in financing. ${ }^{\text {s1 }}$

Employees, who benefit most directly from disability insurance, should also bear part of the cost of the program. But their contribution should not be great. Even though they may be able to shift part of their cost to the employer, this may be unlikely where strong unions are not present. Furthermore, as consumers, workers may be forced to bear a part of the employers' burden. A matching rate of 0.5 percent of payrolls on employers and employees would be both a light load for each party and sufficient for present benefits. ${ }^{82}$ An expanded program should likewise be covered by mutually equivalent payments.

Adjusting each employer's contribution rate according to the rate of disability experienced among his employees has been advocated as a method of computing employers' contributions. ${ }^{\text {s3 }}$ "Experience rating" is extensively

A highly significant aspect of costs is that part of available funds allocated for administrative purposes. Experience with the operating programs suggests that the cost sufficient for effective administration will be less than $5 \%$ of the total revenues. However, prescribing slightly more than is actually needed is not unwise.

Inefficient administration can destroy the effectiveness of disability insurance as a social security device. One of the outstanding features of these programs is that the disabled worker receives his benefits when he most needs them-within a week after he becomes disabled. A tortured claims procedure would vitiate this advantage. Moreover, laxity in checking claims results in malingering and unnecessary costs. Greater efficiency in system operation, in the long run, will decrease costs and make available more funds for additional benefits.

80. See Millis \& Montgosrery, Labor's Risks and Social Insurance 238 (1938): “. . . illness . . . adds to the employers' costs through unbalanced sections which require substitutions of men on the job, and through increased labor turnover. The reduction of output becomes more severe in highly integrated industries, where, for example, the absence of a key man may disrupt a whole assembly line."

81. The employers' contribution, a cost of production, often can be spread over a large number of consumers who pay for it in higher prices. Where the demand is elastic, however, employers may not be able to shift the tax because higher prices would decrease demand. Sometimes employers could pass the tax off on their employees in the form of a refusal to raise wages, especially where the labor organization is weak, or where none exists. See Nat'l Resources Planning Bd., Security, Work, and RELIEF POLICIES 524 (1942).

82. The New York law comes closest to this even match. See note 78 supra.

83. New Jersey already has such a provision. N. J. Laws, 1948, c. 109, §§ 1(d) (e).

Experience rating or merit rating refers to methods by which individual employer contribution rates may be varied from the standard rate, in relation to the employer's past disability record or benefit experience. 
used in unemployment insurance. ${ }^{84}$ Its proponents claim that it would focus the interest of employers on industrial health within their establishments and thus reduce disability. ${ }^{85}$ But disabilities which "arise in the course of employment" are already covered by workmen's compensation. And other disabilities, which are covered by disability insurance programs, are much more likely to be incurred off the job than on it, especially since the average worker spends only about 40 hours of the 168 hours in a week at his job. The most direct way employers can influence the frequency and severity of non-work-connected disabilities is through selective hiring. Such disabilities, after all, are primarily determined by such factors as age, sex, housing, and income. Thus experience rating may increase discrimination in hiring against non-whites, women, older workers and those with chronic ailments. In addition, since merit rating depends in part on the number of claims paid, its use may stimulate contests to assure a favorable experience factor. ${ }^{86}$

Two types of merit rating plans have developed out of unemployment insurance. First, and the most common, is one in which all or a part of an employer's contributions are credited to his account and the benefits paid to his disabled workers are charged to his account. The ratio (reserve ratio) of the excess of contributions over benefits (reserve balance) to his annual or average payroll serves as the basis for modifying contribution rates. Second, variations in contribution rates are based on an index derived by computing the ratio of the amount of wages the employer has paid to his workers during the preceding several years who have subsequently drawn benefits to his total payroll for that period. This benefit-wage ratio is usually called the employer's experience factor.

These plans, as worked out in unemployment insurance, vary slightly from the outline above. In many states the condition of the unemployment insurance fund is taken into consideration in permitting reductions in rates, while in some, only the status of the individual employer's account is considered. See Arnold, Experience Rating, 55 Yale L.J. 218, 229 et seq. (1945); Current Experience Rating Research ApPENDIX B (Social Security Board, Employment Security Memo. No. 7, 1940).

84. Experience rating forms an integral part of all but six state programs. The six require a uniform payroll tax. Arnold, supra note 83, at 219 . For a discussion of weaknesses of experience rating provisions of existing state laws and proposals for a different plan with hypothetical examples, see Pribram \& Booth, Mierit Rating and Unemployarent Compensation (Soc. Sec. Bd. 1937).

85. Two objectives are claimed for experience rating: (1) reduction of disability by inducing employers to improve health factors in the plant, and (2) allocation of the social costs of disability to the individual business concerns largely responsible for those costs. See Arnold, supra note \$3, at 219.

Of unemployment insurance it was said: "Supporters of experience rating point to the more than six billion dollars in the state unemployment funds as one justification of the lower tax rates. They even argue that most state funds are adequate in view of existing benefit provisions. But this is no answer when benefit provisions are deficient." Ellickson, Labor's Demand for Real Employantent Security, 55 YALE L.J. 253, 256 (1945).

86. See Federal Security Agency, Temporary Disability Insurance 51 (rev. ed. 1949). For a summary of labor's objections to experience rating in general, see AFL, Why Must We Repeal Merit Rating Provisions in Uneniployment ConipenSATION (1938). 
In lieu of the payroll tax, a state many choose to finance a program from its annual general revenues. The disability risk is in reality a social problem with which the entire community should concern itself. Spreading the cost would be especially useful in times of depression to help alleviate the tax burden on employers and employees. ${ }^{87}$ And should states remain unwilling to tax government units and non-profit organizations, general appropriations would facilitate coverage of employees of these organizations. ${ }^{88}$ Basically, however, general revenue financing is subject to defects similar to the payroll tax. ${ }^{89}$ Since under present laws general state funds are not garnered principally through graduated income taxes, ${ }^{90}$ the method is no less regressive than a payroll tax. In periods of recession both taxes decrease purchasing power where it is most needed. ${ }^{91}$

The use of general revenues to supplement payroll taxes, however, might be advantageous. ${ }^{22}$ It would enable a state to accumulate a strong reserve fund to meet such contingencies as depression and epidemic. ${ }^{.3}$ And with more funds thus made available benefits can be extended to an adequate level. For

87. From today's viewpoint the immediate future bears little prospect for a decline in employment. But disability insurance is a long range plan. As long as there is a possibility of a rescession it must be planned for in advance. See Comment, 59 YALE L.J. 292, 315 (1950).

88. Such a method could also ensure mandatory coverage of all self-employed persons. The objection to covering the self-employed, i.c., the difficulty in collecting a payroll tax from one who does not earn regular weekly or periodical wages, would no longer obtain.

89. The principal arguments against general revenue financing are first, that disability compensation should not depend on political cross currents and legislative economy drives, and second, that a social insurance program should be truly "insurance," meaning that those who are insured should pay the cost (i.e., premiums). MorT \& Roemer, Rural Health and Medical Care 486 (1949).

90. Census figures for 1948 show that 16 states have no individual income taxes and 15 have no corporate income taxes. In the remaining states, income taxes amounted to a little less than $14 \%$ of total revenues. Total revenues in all states was $\$ 7,790,984$ in 1948. $\$ 499,445$ of this total represented individual income taxes and $\$ 584,823$ corporation income taxes. The Book of States 1950-1951, 254-55, Table 3.

91. Harris, The Economics of Social Security 69-96 (1941).

92. "The Social Security Administration believes that a comprehensive contributory social insurance system should be financed in part through a Government contribution as well as the contributions of employers and employees. Provision for Government contribution for old-age and survivors insurance, if receipts from pay-roll taxes should become insufficient, is already on the statute books. A three-way division of cost makes possible a fair assessment of the three types of responsibility inherent in social insurance-individual, industrial, and social. Since a very large proportion of the population would have protection under such a system, a Government contribution from general tax funds would be warranted. The stabilizing effects of a comprehensive and adequate system would be of importance even for persons who did not share in it directly, and public costs othervise necessary for assistance would be gradually reduced as the insurance system took over responsibilities that must now be financed from general tax funds." FEDERAL SECurITY Agency, Soctal Securttx Administration, Annual Report 1949, 7 (1950).

93. OASI already has a comparable scheme. See note 92 supra. 
example, indemnification benefits, as well as some dependents' allowances and medical services, might be attained at disability costs equal to three percent of payrolls.94 These costs could be financed by contributions of one percent of wages from employees, one percent from employers, and one percent from the state treasury.

\section{Insurance Systeñis}

\section{Systems Available}

A state embarking on a disability program can choose one of several insurance systems within which to integrate coverage, benefits, and financing provisions. It can establish a program operated exclusively by the state; impose a duty upon all employers to insure their own employees, either privately or with the state; or set up a state plan but later permit substituted coverage under private plans approved by a state agency.

Exlusive State Fund. Under the exclusive state fund all contributions are paid to the state, and all benefits are paid by the state. As operated by Rhode Island, ${ }^{95}$ the system is coordinated with unemployment insurance. For administrative purposes, coverage is identical under both insurance laws and the wage records maintained for unemployment insurance are also used for disability insurance. ${ }^{9 B}$

94. On March 7, 1945, the Ives Bill was introduced in the New York State Assembly. It called for health insurance to the same groups of employees covered by unemployment insurance. No cash disability benefits were provided. For medical benefits alone, the Ives Bill demanded a $2 \%$ levy on wages. NICB, Compulsory Sickness CoMpensation FOR NEW York Stare 52, 160 (1947). Since cash disability benefits can be financed at $1 \%$ of payrolls, see note 79 supra, an integrated program would cost $3 \%$.

Among the medical benefits contemplated by the Ives Bill were such basic services as diagnostic and therapeutic treatment by physicians, $\mathrm{X}$-ray treatments, hospitalization for 21 days, drugs, a general health examination by a physician once a year for an insured and for each of his dependents, and dental services. Additional services could be granted if the financial resources of the fund warranted them. These included increased hospitalization periods, additional drugs, medical, dental and optometrical services. Id. at 53 . If these benefits look too good to be true at the price (2\%), some can be cut. For the purposes of disability insurance (not health insurance), for instance, yearly examinations and medical benefits to dependents are unnecessary. The worker needs insurance when unable to draw regular income, i.e., when disabled. So long as he is physically fit, and working, he is more able to pay for both his own check-ups, as well as his dependent's.

Over generalization as to cost is unwise because of wide variations from state to state in disability factors, medical facilities and cost of living. See note 79 supra. But 3\% should be able to buy considerable benefits everywhere.

95. See Muntz, Growtr and Trends in Soctal Security, NICb, Studies No. 6, 88-93 (1949).

96. An exhaustive analysis of the exclusive state fund, as compared with other systems of assuring coverage can be found in STUDIES IN DisabiLITy INsurance 75 et seq. (N. Y. Dep't Labor 1949). 
Employer Liability with Competitive State Fund. In contrast to the exclusive state fund, employer liability with competitive state fund permits employers to establish private plans, either by purchasing group insurance policies from commercial carriers or by self-insurance. A state insurance fund is established to afford protection to poorer risks rejected by private insurance, but any employer may insure in this fund. Claims must be presented directly to the employer, and are paid by his insurer. ${ }^{97}$ The state agency administering the law exercises general supervision over all plans, to see that they provide specified minimum benefits at no more than maximum employee assessments. New York, which has enacted this system, ${ }^{98}$ provides for administration by its Workmen's Compensation Board. That state has also established a special state fund to cover the disabled unemployed who have no employers to whom they can present their claims. ${ }^{99}$ This special fund is financed by assessments on insurance companies, self-insurers, and the state insurance fund. ${ }^{100}$

Contracting-Out. California ${ }^{101}$ and New Jersey ${ }^{102}$ have adopted a so-called "contracting-out" system which is quite similar to the employer liability with competitive state fund system. Under contracting-out, a state benefit fund is established to which all contributions are made unless a state-approved private insurance plan is substituted by employer-employee agreement. ${ }^{103}$ The private plan may be underwritten by a commercial carrier or sustained by self-insurance. Payments for the private plan may be made by employees, subject to the statutory maximum established for the state fund. Any additional costs must be satisfied by the employer. ${ }^{104}$ Workers must file their claims with the insurer-state or private-under whose plan they are covered at the time they

97. I.e., either by a private insurance company or by the state fund, depending unon which the employer is insured with.

98. N. Y. Laws, 1949 , c. $600 \S 211$. This system is modeled after New York's workmen's compensation law.

99. Id. $\$ 214$.

100. Lbid.

101. See description of California's law in MUNTz, op. cit. supra note 95, at 93-98; Federal Security Agency, California Disability Insurance Program 5, 20 et seq. (1948).

102. See Muntz, op. cit. supra note 95, at 98-102; Studies IN DisabiLity INsurANCE 35-39 (N. Y. Dep't Labor 1949).

103. In requiring employee approval before an employer can use a private insurer, contracting-out differs from the employer liability system. But in other respects the two systems are very much alike, except for the fact that in the beginning, at least, a contracting-out system will have a much greater percentage of employers covered by the state fund. In the long run, however, so many firms may contract out of the state fund that the ratio between state and private plan coverage in both systems will become equal.

104. In California, for example, employees are not required to contribute to private plans. If they do, the $1 \%$ maximum established for the state fund applies. Although employers do not contribute to the state plan they can bear the entire cost of a private plan. Cal. Gen. Laws \$ 456 (1947). 
become disabled. The state agency handles contested claims for all plans, and administration is coordinated with unemployment insurance.

\section{Choice of System}

Many arguments are marshalled in support of the employer liability and contracting-out systems. ${ }^{105}$ Private plans can more readily adjust the particular needs and risks in the individual plant. And administration, being closer to the industrial establishments, tends to be more efficient. 106 In addition, competition among insurance carriers assures strict policing of claims and stimulates efforts to extend the greatest benefit at the lowest premium. ${ }^{107}$

The defects in the employer liability and contracting-out systems, however, outweigh their advantages. Since private plans tend to select the employers who hire better disability risks, under these systems employers of poorer risks would have to be covered by a state fund. ${ }^{108}$ Thus annual contributions

105. Many have pitched their arguments on a politically emotional level. See, c.g., Zucker, The Nezo York Disability Benefits Laze-The Model Approach, 4 Industrial and Labor Relations Rev. 420 (1951). For more factual analyses see Studies In Disability Insurance 75 et seq. (N. Y. Dep't Labor 1949); Federal Security Agency, Temporary Disability Insurance 36-45 (rev. ed. 1949); The New York Disability Benefit System, 4 Industrial and Labor RELations Rev. $415-438$ (1951).

106. See Studies in Disability Insurance 94 (N. Y. Dep't Labor 1949).

107. Another argument is made that it is easier for a group to increase their protection on their own without waiting for legislative action affecting the entire state. Hence greater immediate benefits can be expected. Studirs IN Disabirity Insurance 93 ( $N$. Y. Dep't Labor 1949). But a similar argument can be made in support of an exclusive state fund. Private insurance can supplement the state program. See page 671 infra.

108. Groups with better than average disability experience would benefit from contracting-out. They could secure greater benefits for the same cost or equal benefits for a lower cost. Groups with poorer experiences would have to pay as much or more for the same benefits with private insurance. It is to their advantage therefore to remain in the state fund. Thus gradually the state fund will find itself covering poorer risks. For an excellent discussion see Studies IN DisabILITy Insurance 87-92 (N. Y. Dep't Labor 1949).

Early experience in California indicates that state-plan workers are older than the aggregate of private plan workers. In addition the state plan includes a much greater percentage of women, workers with lower average wages, and less regular employment. Ibid.

Several solutions to adverse selection have been proferred. The California law gives discretion to the state agency to disapprove private plans which tend toward adverse risk selection. To date only one test has been devised. The aggregate voluntary plan coverage of each carrier must include at least $20 \%$ female workers. Any plan which would bring below $20 \%$ the number of female workers covered by a carrier will be disapproved. Note, however, that the state plan nevertheless contains a higher proportion of women covered. Another proposal was made in the New Jersey legislature. Those who contract-out from state plan coverage normally are excused from contributions to the state. But under this proposal they would continue to be obligated to pay from $.1 \%$ to $.25 \%$ to the state plan, depending on the amount required to maintain equal loss-ratios between state and private plans. The proposal was defeated, how- 
to this fund may not be adequate to cover its disbursements. ${ }^{109}$ Private plans are also less effective because the selling expenses of private carriers, and their need to show profits, mean that a smaller proportion of the premium dollar can be utilized for benefits. ${ }^{110}$ And since a state agency must police private plans, such plans present greater administrative problems and increase the costs of an entire program. Finally, adoption of empoyer's liability or contracting-out makes financing through general revenues less likely, since a legislature may balk at appropriating state revenues to pay premiums to private insurance companies.

In contrast the features of an exclusive state fund demonstrate its desirability. Since all workers, both good and bad risks, are covered by one fund, the financial dangers of adverse risk selection are avoided. Moreover, administrative costs of a single state insurance fund are small, especially if coordinated with unemployment insurance. ${ }^{111}$ The exclusive fund also adds simplicity of claims procedures, ${ }^{112}$ and eliminates the need for a special fund to cover the eligible unemployed. ${ }^{113}$

ever, upon the outcry of private insurance that such a tax would be a penalty tax, giving unfair advantage to the state plan by discouraging contracting-out.

109. Since the state fund is left to cover poorer risks the rate of disability will be higher than originally expected with all risks pooled under one plan. Costs will thus be greater than $1 \%$ of payrolls. In addition higher paid workers are more likely to contract-out of the state fund, leaving a smaller base for the $1 \%$ tax. See ibid.

110. For the period 1938-42 total expenses of commercial group insurance exclusive of taxes, licenses and fees, came to $19 \%$ of premiums. And this figure does not account for dividends or other refunds to policyholders. Blanchard, Survey of Accident aNd Healte Insurance (Federal Security Agency, Bureau of Research and Statistics Memo. No. 62, 1946). Hence of the premium dollar something less than $80 \%$ will be channeled into benefits.

Typical expenses incurred are for investigation and adjustment, acquisition and field supervision, general administration of inspection and bureau expenses, taxes, licenses and fees, and dividends to policyholders.

111. No acquisition costs or profit motive attend an exclusive state fund. And when coordinated with unemployment insurance, wage records and employers' accounts need not be duplicated. The same argument, however, supports coordination with workmen's compensation. In fact the latter has an additional advantage. In the event that disability benefits are extended to include medical services, workmen's compensation agencies already have the trained personnel and mechanics to handle the special problems thereby created. Unemployment insurance boards do not.

112. Under one overall insuring body, claim forms, physicians' reports and procedural regulations easily can be made uniform. No difficulty arises from employers shifting their insurance from state fund to numerous private carriers or self-insurance. Claimants need direct their attention to but one insurer.

113. A private plan covers only workers actually employed or those who fall sick within a short time after becoming unemployed. In New Jersey the private carrier is responsible for benefits for two weeks after the worker leaves the employ of an insured employer. N. J. Laws, 1948, c. 110, §3(b). In New York the period is four weeks. N. Y. Laws, 1949 , c. 600 , $\$ 203$. In California, the insurance company is absolved from responsibility as soon as the worker terminates employment. Cal. Adm. Code tit. 22, §283(d). But the private carrier cannot forever be responsible 
Even though the exclusive state fund system is adopted, commercial group accident and health insurance need not be scrapped. Private plans can continue in operation to supplement, rather than substitute for, state fund protection. ${ }^{114}$ This would allow higher paid workers, the major buyers of commercial insurance anyway, to help close the gap between wages lost and state benefits paid.

\section{The NeEd for Federal Supervision}

To the extent that four states extend compulsory insurance to cover temporary disabilities they are making a real contribution to the security of the working population. The disability risk, however, is not confined to these few states; the problem is nationwide. Yet progress among other states has been slow.

Moreover, as now developing, state programs will result in a disparate patchwork of coverage, benefits, financing, and administration. Such a haphazard approach entails real dangers. Unequal insurance rates among the states may lead to unequal costs among competing firms and a restriction of coverage and benefit provisions. The emergence of many different plans with myriad benefit provisions and qualifications may result in loss of protection to employees who move from job to job or from state to state. ${ }^{115}$ And the coexistence of public and private plans is an expensive and burdensome method of insuring.

Therefore, a national approach to temporary disability insurance is needed to obtain a single, uniform program. Minimum standards for finances, coverage, and benefits could be established by Congress through a new title to the Social Security Act. Like unemployment insurance, credits could be given against federal payroll tax liability for contributions to exclusive state funds which meet minimum federal standards. Basic uniformity could thus be assured. At the same time the program would be flexible enough for states to make provision for varying risk and cost factors. States wishing to grant more than the minimum benefits could do so. Moreover, decentralized administration is more likely to afford individualized attention to the rank and file in the labor force and facilitates strict checking of claims to prevent malingering.

for paying benefits to unemployed workers. Such persons must look to the state. The state can get funds to pay these benefits either from general revenues or from assessments upon private carriers and self-insurers.

114. The exclusive state fund in Rhode Island has had a salutary effect on the business of private health and accident insurance as a supplement to state insurance. Barkin, Comments on The New York Disability Benefits System, 4 Industrial and Labor Relattons Rev. 429 (1951).

115. In this critical era of increased defense production, mobility of labor is desirable. But if a worker is required to move from one employment to another, perhaps in a different geographical area, he should not be in jeopardy of losing protection under disability insurance. This may occur if eligibility requirements and benefits are not uniform throughout the states. 
Social insurance has proved to be the most feasible way to help mitigate the economic hardships which unemployment, industrial mishaps, old age and death inflict upon workers and their families. The equally grave risk of disability should be met in the same manner. 